Rewah. They consist of a basioccipital and basisphenoid, with minute fragments of the maxillary bone and a dorsal vertebra. The evidence of the genus Parasuchus, a crocodilian type from Maleri, consists of similar remains rather better preserved, and includes the articular part of the quadrate bone, a fragment of the premaxillary, and what the author regards as dermal scutes. It is considered that some other fragments indicate a Dinosaur; but the remains are not of that conclusive character that might be desired, consisting of a fragment of a dorsal vertebra of Teleosaurian type, a caudal vertebra, and a phalange. The phalange has a more Dinosaurian aspect than the other bones. There are some teeth, referred to the same type, which resemble the hinder teeth of Belodon as well as Thecodontosaurus.

The remains of Mastodonsaurus are said to consist of the right supratemporal bone found in the Denwa group, on the Denwa river, in the Satpura district. Other fragmentary specimens are stated to be allied to Metopias of Von Meyer and Capitosaurus of Münster. A portion of a maxillary bone shows teeth with folded enamel, each having a quadrate base with a pulp-cavity. There are also fragments of cranial bones, mandible, and vertebræ. All these remains are of so fragmentary a character that more than ordinary courage was needed to refer to them at all, and the conclusions adopted are necessarily speculative. The volume concludes with a list of memoirs which relate to these fossils, followed by a synopsis of the Pretertiary Indian Vertebrata.

\title{
MISCELLANEOUS.
}

\section{Some new Infusoria from American Fresh Waters.}

Is the 'Annals' for February last, under the above title, the present writer published an article in which a new genus of Infusoria was formulated with the name Diplomastax, the word Diplomestoma, which I had selected and written in my MS., having been cancelled by the Editors under a misapprehension for which I gave them one excuse, it seems, by my mistake in writing "Diplomastax" in the explanation of the plate, and another by deriving Diplomestoma in an utterly impossible way, according to the editorial note in the April number of the magazine. Therefore, since Diplomastax is preoccupied and the derivation of Diplomestoma is offensive to the purist, I withdraw it and substitute the name Dallasia, in honour of Mr. W. S. Dallas, F.L.S., Assistant Secretary of the Geological Society, to whom it affords me much pleasure to dedicate the genus, the name of the species described thus becoming Dallasia frontata instead of Diplomestoma frontata.

Trenton, New Jersey, U.S. A. 


\section{On Entoniscus mænadis. By M. A. Giard.}

Almost at the moment when I made known the existence on the French coasts of the Entoniscus parasitic upon Pachygrapsus marmoratus, Fab.*, P. Fraisse met with this curious Isopod in the Bay of Naples, that is to say in the locality where it was discovered in 1787 by Cavolini. Fraisse further stated $\uparrow$ that he had found the same parasite in Carcinus mcenas, but he did not establish the correctness of this determination by the comparative examination of the embryos, which furnish the best specific characters in creatures which are so profoundly modified in the adult state. As I had observed at various points on the shores of the Channel embryos of Entoniscus which had strayed into the incubatory cavity of Sacculince Carcini, I repeatedly sought for Entoniscus in Carcinus monas, but always without success, notwithstanding the great number of crabs which were sacrificed for this purpose.

I have been more fortunate this spring, and the first crab which I opened at Wimereux furnished me with a fine Entoniscus, the ovigerous lamellæ of which contained perfectly mature embryos. The infested Carcinus manas was a female of middle size, bearing a Sacculina the incubatory cavity of which was empty. The Entoniscus was placed on the left side of the crab, in the midst of the hepatic cæca of its host.

This Entoniscus, which I shall call Entoniscus mcenadis, is very distinct from Entoniscus Cavolinii. The liquid which circulates in the vessels contrasts by its red colour with the orange-yellow ground of the ovarian mass. The ovigerous sac, or, to be more exact, the mass of embryos ready for exclusion, presents a mauve-grey coloration, very different from the leaden tint of Entoniscus Cavolinii loaded with ova in the same stage of development. The embryo, especially, presents easily recognizable differential characters. We find no trace of the remarkable Nauplian eye, the existence of which I have indicated in the parasite of the Grapsus. The crystallines of the lateral eyes are more approximated, and from these eyes there start, on each side of the head, arcs of a reddish-brown pigment which meet upon the median part of the forehead. The sixth pair of thoracic legs presents nearly the same conformation as the corresponding pair in the embryo of $E$. Cavolinii; nevertheless the terminal rod is shorter, and does not support a tuft of hairs as in the latter. From this point of view E. Cavolinii and E. manadis differ greatly from $E$. Salvatoris, Kossmann, in which the six pairs of thoracic feet are all similar $\ddagger$.

Kossmann has placed beyond doubt the existence of the male in the European Entonisci§. Further, he has supposed that in the

* 'Comptes Rendus,' August 12, 1878.

† Arbeiten a. d. zool.-zoot. Inst. zu Würzburg, Bd. iv. 1878.

I I resume, for the parasite of Portunus arcuatus, the name originally given by Kossmann, because this parasite appears to me to be specifically distinct from that of Portunus puber, E. Moniezii, with which Kossmann would identify it.

§ See Kossmann's paper translated in the Ann. \& Mag. Nat. Hist. ser. 5, vol. x. p. 81. 


\section{$2 \mathrm{BHL}$ Biodiversity Heritage Library}

Stokes, Alfred C. 1886. "Some new Infusoria from American fresh waters." The Annals and magazine of natural history; zoology, botany, and geology 17, 534-535. https://doi.org/10.1080/00222938609460189.

View This Item Online: https://www.biodiversitylibrary.org/item/53478

DOI: https://doi.org/10.1080/00222938609460189

Permalink: https://www.biodiversitylibrary.org/partpdf/52307.

\section{Holding Institution}

Smithsonian Libraries

\section{Sponsored by}

Smithsonian

\section{Copyright \& Reuse}

Copyright Status: Public domain. The BHL considers that this work is no longer under copyright protection.

This document was created from content at the Biodiversity Heritage Library, the world's largest open access digital library for biodiversity literature and archives. Visit BHL at https://www.biodiversitylibrary.org. 